\title{
A Review of Hemostasis in Normal Pregnancy and Puerperium
}

\author{
Bushra Moiz* \\ Department of Pathology and Laboratory Medicine, The Aga Khan University Hospital, Karachi, Pakistan.
}

\begin{abstract}
Significant alterations are seen in hemostatic system during normal pregnancy and puerperium. Overall, it is a state of hypercoagulability and hypofibrinolysis mitigating the risk of severe bleeding during placental separation at delivery. On the flip side, it threatens a pregnant woman for thrombosis with the risk being four to six folds more in comparison to a non-pregnant woman. It is important to understand the hemostatic changes in normal pregnancy by all health care providers who manage pregnant women in obstetric wards, trauma, anesthesia and other circumstances. This review describes the changes in qualitative and quantitative changes in platelet, clotting factors, anticoagulants and fibrinolysis during normal pregnancy and puerperium.
\end{abstract}

Keywords: Clotting factors, Fibrinolysis, Hemostatic system, Hypercoagulability, Hypofibrinolysis, Pregnancy, Puerperium. doi.org/10.21089/njhs.23.0123

\section{INTRODUCTION}

Normal pregnancy poses significant challenges to hemostasis. Overall, it is a state of hypercoagulability with hypofibrinolysis mitigating the risk of bleeding at the time of delivery [1]. These physiological variations place a woman at risk of thrombosis during pregnancy and puerperium [2]. This risk is four to six fold high in comparison to a nonpregnant woman [3]. There is a paucity of literature describing obstetric thrombosis at national level $[4,5]$. In this review, hemostatic changes in normal pregnancy and puerperium will be described followed by their practical implications.

\section{QUANTITATIVE CHANGES IN PLATELETS}

Reference interval of platelet count is $150-400 \times 10^{9} / \mathrm{L}$. Low platelet count $\left(<150 \times 10^{9} / \mathrm{L}\right)$ or thrombocytopenia during normal pregnancy was noticed during early years utilizing manual techniques. Sejeny in 1975 [6] was the first to report gestational thrombocytopenia in 405 healthy pregnant women using electronic particle counter [6]. Since then, a number of global reports described a sequential reduction of platelet count as pregnancy advances [7-18] with a $10-20 \%$ fall in platelet count [19]. Frequency of gestational thrombocytopenia was estimated to be $7-12 \%$ at term $[12,14,15]$. A platelet count of $80 \times 10^{9} / \mathrm{L}$ is considered to be a safe threshold [20] with no impact on either mother [21] or the fetus [15], unless the thrombocytopenic mother has some comorbids[14]. Mothers having platelet count of $150 \times 10^{9} / \mathrm{L}$ at $28^{\text {th }}$ week of gestation have a pre-birth platelet count $>100$

*Address correspondence to this author at the Department of Pathology and Laboratory Medicine, The Aga Khan University Hospital, Karachi, Pakistan; Tel: 02133101302/4511; Email: bushra.moiz@aku.edu x $10^{9} / \mathrm{L}$ and can safely receive epidural [22]. Only $2.1 \%$ of neonates born to thrombocytopenic mothers had thrombocytopenia. This is not significantly different from $2.0 \%$ neonates with thrombocytopenia born to non-thrombocytopenic mothers [15]. Why maternal thrombocytopenia is observed? It is reasonable to believe hemodilution $[6,23]$ as one of the contributory factors. As pregnancy advances both plasma volume and red blood cells increase but not to the same proportion with consequential dilution thrombocytopenia [24]. Another possible mechanism is an increased consumption of platelets inside utero-placental circulation $[7,8]$ accelerating thrombopoiesis in bone marrow. As a result, an increase in mean platelet volume (MPV), platelet distribution width and large-size platelets in peripheral film were observed in many $[7,9,17,25]$ but not all reports $[18,26]$. Large-sized platelets may be pathogenic [27] but since platelet turnover is usually normal [20] and platelet count is low therefore, overall effect is a balanced platelet mass [7]. Usually, the platelet count normalizes within 4-6 weeks after delivery [20].

\section{QUALITATIVE CHANGES IN PLATELETS AND ACTIVATION MARKERS}

Platelets are an important constituent of primary hemostasis. This requires platelets to adhere, secrete and aggregate at the site of injury. Platelet function was measured historically through bleeding time. Recently, a number of sub global (e.g. platelet aggregometry, platelet activation markers and flowcytometry) and global assays (e.g. PFA-100, and flow chambers) had been utilized evaluating platelet function in pregnancy.

The bleeding time is unchanged during normal pregnancy [20]. As traditional bleeding time determination methods lack the sensitivity and specificity required for detecting 
platelet dysfunction, its utility is seriously challenged [28]. $\beta$-thromboglobulin (BTG) is an index of invivo platelet activation. There is controversy regarding BTG where both increased [29] and normal [30, 31] levels were reported. Adenosine deaminase (ADA) is the enzyme that breaks down adenosine - an inhibitor of platelet aggregation. Increased ADA activity has been reported in third trimester compared to non-pregnant controls [32]. This was hypothesized to maintain local hemostasis prior to and during delivery [32]. Mircoparticles (MP) are tissue factors containing vesicles, derived from a number of cells including platelets. Their numbers initially decrease and subsequently normalize during pregnancy [33]. However, labor and delivery appear to be associated with an increase in the number of platelet-derived MPs indicating increased pro-coagulant activity [34].

Point-of-care device, PFA-100, is the platelet function analyzer that estimates the speed with which platelets form a plug in vitro by measuring closure time. The collagen membrane used in PFA-100 is impregnated with platelet activators (ADP and epinephrine). Mean closure time using epinephrine was reported as $105 \pm 18$ seconds [35] and 114.6 \pm 27.3 seconds [36] in 93 and 110 healthy pregnant women respectively. Both studies did not include a control group of non-pregnant women. Their reported closure time was not significantly different from closure time of $108 \pm 22$ seconds reported in healthy women [37].

Platelet aggregometry evaluates function as platelet clumps in response to agonists (ADP, epinephrine, collagen, arachidonic acid and thrombin) with subsequent increased light transmission in plasma or whole blood. Platelet hyperaggregation during third trimester was reported in a number of studies suggesting hyper functioning platelets near labor [38-40] . Recently reduced platelet aggregation was observed using a modified technology in light transmission aggregometry [41]. In contrast to hyper-functioning platelets as observed on aggregometry, flowcytometry failed to show any increase in activated platelets during normal pregnancy [40, 42], rather a decrease platelet adhesion and thrombus growth on collagen or fibrinogen was observed using flow condition [40]. The controversy regarding platelet functioning in pregnancy (either normal, reduced or increased) can be resolved by doing various types of platelet studies simultaneously in a large cohort of pregnant women.

\section{VARIANCE IN COAGULATION FACTORS}

Platelet aggregates are stabilized by fibrin resulting from activation of clotting factors at the site of injury. Both extrinsic and intrinsic factors are involved. Normal pregnancy is accompanied by a progressive rise in clotting factors II, V, VII, VIII, IX, X, XII, fibrinogen [3, 19, 20, 43, 44], von Willebrand factor (vWF) [21] and tissue factor [45]. However stable and non-rising trends in II, X, XI were also reported
[46]. The rise in clotting factors is considered to be a consequence of hormonal changes particularly estrogen [23]. There are conflicting reports regarding factor XIII during pregnancy with reports of both increase and decrease levels. A prospective study on a cohort of 44 women with normal pregnancy showed a $17 \%$ fall in factor XIII activity compared to 8-week postpartum [19]. This was considered as an effect of consumption similar to the pathogenesis of maternal thrombocytopenia. Overall, there is no effect on prothrombin time (PT) and activated partial thromboplastin time (APTT) [46].

\section{CHANGES IN ANTICOAGULANTS}

A number of circulating anticoagulants counterbalance clotting factors restricting their activation to the site of injury. Total protein S (PS), protein C (PC) and anti-thrombin III (ATIII) are stable through pregnancy [46-48] and during postpartum [46]. However, there is a progressive fall in free PS, PS activity [46-49] with acquired PC resistant [3, 48] and a rise in thrombomodulin (TM), tissue factor pathway inhibitor and heparin cofactor II [50]. A progressive increase in protein $\mathrm{C}$ activity was reported in first and second trimester which supposedly counterbalance the fall in protein $\mathrm{S}$ activity and rise of thrombin for maintaining good fetal circulation [49]. A study evaluating PC, PS and ATIII in 50 pregnant women at $37^{\text {th }}$ week of gestation and 42 days postpartum indicated a sharp rise in their levels from $3^{\text {rd }}-7^{\text {th }}$ postpartum day onwards [51].

\section{HYPOFIBRINOLYSIS}

Normally, fibrin generated as a consequence of active coagulation is restricted to its site of formation by plasminogen. This fibrinolysis is in fine balance because of plasminogen activator and its counteracting plasminogen activator inhibitor. Fibrinolysis generates fibrin degradation products and a specific marker D-dimer resulting from breakdown of crosslinked fibrin by plasmin. Fibrinolysis prevents clot formation in an intact cardiovascular system maintaining vascular sufficiency.

It was observed earlier that systematic fibrinolysis is decreased in normal pregnancy using euglobulin lysis time. It was also realized that plasminogen and anti-plasmin concentrations rose during pregnancy [52]. This is considered related to their decreased utilization and increased production [20]. The overall effect is marked decrease in fibrinolytic activity from 11-15 weeks onwards [44]. Hypofibrinloysis is mainly because of significantly increased levels of plasminogen activator inhibitor-1 (PAI-1) from endothelial cells and plasminogen activator inhibitor-2 (PAI-2) from the placenta while thrombin-activated fibrinolysis inhibitor is unaffected [20] .

Despite hypofibrinolysis, fibrin degradation products (FDPs) rose from 21-25 weeks onwards [44]. D-dimer also increases 
as pregnancy progresses [3] rising two- to four-fold by delivery [53]. The underlying reason for raised FDPs and Ddimers is excess thrombin formation because of increased clotting factors. Increased in-vivo thrombin generation [54] is reflected through raised prothrombin fragment $1+2$, thrombin-anti-thrombin complex, fibrinopeptide A, soluble fibrin and plasmin-antiplasmin complex [20]. The findings are consistent with a mild degree of local intravascular coagulation from early on in pregnancy in some women [44] without signs of organ dysfunction during normal pregnancy [20] .

The impaired fibrinolysis resumes normality soon after delivery of the baby [3, 52]. Blood coagulation and fibrinolysis variables have been studied in the normal puerperium. Factor VIII activity and related antigen, fibrinogen, fibrinopeptide A, antithrombin III, plasminogen, tissue plasminogen activator (t-PA), fast inhibitor of t-PA, alpha 2-antiplasmin, urokinase inhibitors, fragment $\mathrm{B}$ beta 15-42 and kallikrein inhibition were analyzed. Both blood coagulation and fibrinolysis were significantly increased during the first 2 weeks normalizing in $3^{\text {rd }}$ week post-partum [55].

\section{GLOBAL CHANGES IN HEMOSTATIC ABNORM- ALITIES}

Thromboelastography (TEG) is a global hemostatic test that measures the elastic properties of blood including strength, rate and stability of clot formation [56]. Clotting factors are measured by ' $R$ ' which is the time lapse between blood sample placement in TEG analyzer and initial fibrin formation. Fibrinogen is measured by clot kinetics ( $\mathrm{K}$ and $\alpha$ ) describing a pre-determined strength of clot formation. Clot strength (MA) is clot firmness and depends on platelet count and function. Clot stability (LY 30) measures the time taken for clot breakdown 30 minutes after maximum strength has been achieved and reflects fibrinolysis. In normal pregnancy ' $R$ ' and 'LY' 30 are shortened while 'MA' and ' $\alpha$ ' were higher $[57,58]$ indicating an increase in clotting factors, fibrinogen and hypercoagulability. These changes are reverted in 8weeks postpartum [58].

\section{PRACTICAL IMPLICATIONS OF PHYSIOLOGICAL CHANGES IN HEMOSTASIS}

Usually, hemostatic reference intervals are based on samples from non-pregnant women. Since there are hemostatic alterations in normal pregnancy and puerperium, the health care providers should be mindful of these changes. Reference intervals of various parameters in normal pregnancy and puerperium have been defined in several reports $[12,14,16$, $22,23,46-49]$. It is important that laboratories analyzing coagulation profile in pregnant women should use these reference intervals. Moreover, reference intervals for global hemostatic testing such as platelet function $[35,36]$ and thromboelastography $[57,59]$ in normal pregnancy have also been defined.

\section{CONCLUSION AND WAY FORWARD}

Normal pregnancy and puerperium significantly alter hemostatic system. The platelet count fall up to $80-100 \times 10^{9} / \mathrm{L}$ near term while platelet functioning is controversial as different results are observed in aggregometry and flowcytometry. Clotting factors II, V, X, XI, XII, antithrombin, protein $\mathrm{C}, \mathrm{PT}$ and APTT largely remained unchanged during normal pregnancy, labor and puerperium. However, levels of factor VII, VIII, IX, fibrinogen and D-dimer increase markedly. Protein S activity decreases markedly while total protein $\mathrm{S}$ is stable. Overall, pregnancy and puerperium is a state of hypofibrinolysis and hypercoagulability.

Where do we stand? At national level, there are few studies describing thrombosis during pregnancy and postpartum. We need large scale studies focusing on obstetric thrombosis to determine the true magnitude of this burden in our population.

\section{CONFLICT OF INTEREST}

Declared none.

\section{ACKNOWLEDGEMENT}

Declared none.

\section{REFERENCES}

[1] Heit JA, Kobbervig CE, James AH, Petterson TM, Bailey KR, Melton LJ $3^{\text {rd }}$. Trends in the incidence of venous thromboembolism during pregnancy or postpartum: a 30-year population-based study. Ann. Intern. Med., 2005; 143(10): 697-706. DOI: 10.7326/00034819-143-10-200511150-00006

[2] Valera MC, Parant O, Vayssiere C, Arnal JF, Payrastre B. Physiologic and pathologic changes of platelets in pregnancy. Platelets, 2010; 21(8): 587-95. DOI: $10.3109 / 09537104.2010 .509828$

[3] Brenner B. Haemostatic changes in pregnancy. Thromb. Res., 2004; 114(5-6): 409-14. DOI: 10.1016/j.thromres.2004.08.004

[4] Khealani BA, Wasay M, Saadah M, Sultana E, Mustafa S, Khan FS, et al. Cerebral venous thrombosis: a descriptive multicenter study of patients in Pakistan and Middle East. Stroke, 2008; 39(10): 2707-11. DOI: 10.1161/STROKEAHA.107.512814

[5] Zamir Q, Shah AR, Bhatti AM, Wajid AA. Frequency of proven risk factors for deep vein thrombosis in clinical patients: results of a study on patients being treated at a tertiary care hospital in Rawalpindi, Pakistan. J. Pak. Med. Assoc., 2015; 65: 110-2.

[6] Sejeny SA, Eastham RD, Baker SR. Platelet counts during normal pregnancy. J. Clin .Pathol., 1975; 28: 812-3. DOI: $10.1136 /$ jcp.28.10.812

[7] O'Brien JR. Letter: platelet counts in normal pregnancy. J. Clin. Pathol., 1976; 29: 174. DOI: 10.1136/jcp.29.2.174-a

[8] Fay RA, Hughes AO, Farron NT. Platelets in pregnancy: hyperdestruction in pregnancy. Obstet. Gynecol., 1983; 61: 238-40. DOI: https://doi.org/10.1097/00132582-198312000-00003

[9] Sill PR, Lind T, Walker W. Platelet values during normal pregnancy. Br. J. Obstet. Gynaecol., 1985; 92: 480-3. DOI: 10.1097/00006254-198602000-00003 
[10] Lamparelli RD, Baynes RD, Atkinson P, Bezwoda WR, Mendelow BV. Platelet parameters part I: platelet counts and mean platelet volume in normal and pregnant subjects. S. Afr. Med. J., 1988; 73: 36-9.

[11] Karim SA, Khurshid M, Rizvi JH, Jafarey SN, Rizwana I. Platelets and leucocyte counts in pregnancy. J. Pak. Med. Assoc., 1992; 42(4): 86-7.

[12] Ahmed Y, van Iddekinge B, Paul C, Sullivan HF, Elder MG. Retrospective analysis of platelet numbers and volumes in normal pregnancy and in pre-eclampsia. Br. J. Obstet. Gynaecol., 1993; 100: 216-20. DOI: http://dx.doi.org/10.1111/j.1471-0528.1993.tb15233.x

[13] Mercelina-Roumans PE, Ubachs JM, van Wersch JW. Platelet count and platelet indices at various stages of normal pregnancy in smoking and non-smoking women. Eur. J. Clin. Chem. Clin. Biochem., 1995; 33(5): 267-9. DOI: 10.1515/cclm.1995.33.5.267

[14] Boehlen F, Hohlfeld P, Extermann P, Perneger TV, de Moerloose P. Platelet count at term pregnancy: a reappraisal of the threshold. Obstet. Gynecol., 2000; 95(1): 29-33. DOI: 10.1097/00006250200001000-00006

[15] Sainio S, Kekomaki R, Riikonen S, Teramo K. Maternal thrombocytopenia at term: a population-based study. Acta Obstet. Gynecol. Scand., 2000; 79: 744-9. DOI:10.1034/j.16000412.2000.079009744.x

[16] Morikawa M, Yamada T, Yamada T, Koyama T, Akaishi R, Ishikawa S, et al. Antithrombin activity, platelet count, hemoglobin concentration and hematocrit value determined immediately before vaginal delivery among healthy women. Hokkaido Igaku Zasshi., 2012; 87: 141-6.

[17] Han L, Liu X, Li H, Zou J, Yang Z, Han J, et al. Blood coagulation parameters and platelet indices: changes in normal and preeclamptic pregnancies and predictive values for preeclampsia. PLoS One, 2014; 9(12): e114488.

DOI: https://doi.org/10.1371/journal.pone.0114488

[18] Li A, Yang S, Zhang J, Qiao R. Establishment of reference intervals for complete blood count parameters during normal pregnancy in Beijing. J. Clin. Lab. Anal., 2017; e22150. DOI: $10.1002 /$ jcla.22150.

[19] Karlsson O, Jeppsson A, Hellgren M. A longitudinal study of factor XIII activity, fibrinogen concentration, platelet count and clot strength during normal pregnancy. Thromb. Res., 2014; 134(3): 750-2. DOI: 10.1016/j.thromres.2014.07.005

[20] Hellgren M. Hemostasis during normal pregnancy and puerperium. Semin. Thromb. Hemost., 2003; 29(2): 125-30. DOI: 10.1055/s2003-38897

[21] Cadroy Y, Grandjean H, Pichon J, Desprats R, Berrebi A, Fournie A, et al. Evaluation of six markers of haemostatic system in normal pregnancy and pregnancy complicated by hypertension or preeclampsia. Br. J. Obstet. Gynaecol., 1993; 100(5): 416-20. DOI: 10.1111/j.1471-0528.1993.tb15264.x

[22] Duong C, Kidson-Gerber G, Peters N, Listijono DR, Henry A. Trajectory of platelets in pregnancy - do low-risk women need an intrapartum full blood count prior to epidural?. Aust. NZJ. Obstet. Gynaecol., 2015; 55(5): 511-4. DOI: 10.1111/ajo.12362

[23] Abbassi-Ghanavati M, Greer LG, Cunningham FG. Pregnancy and laboratory studies: a reference table for clinicians. Obstet. Gynecol., 2009; 114(6): 1326-31. DOI: 10.1097/aog.0b013e3181c2bde8

[24] Katz D, Beilin Y. Disorders of coagulation in pregnancy. Br. J. Anaesth., 2015; 115(Suppl 2): 75-88. DOI: 10.1093/bja/aev374

[25] Singer CR, Walker JJ, Cameron A, Fraser C. Platelet studies in normal pregnancy and pregnancy-induced hypertension. Clin. Lab. Haematol., $\quad 1986 ; \quad 8(1)$ : 27-32. DOI: 10.1111/j.13652257.1986.tb00072.x
[26] Liu XH, Jiang YM, Shi H, Yue XA, Wang YF, Yang $H$ Prospective, sequential, longitudinal study of coagulation changes during pregnancy in Chinese women. Int. J. Gynaecol. Obstet., 2009; 105(3): 240-3.

[27] Leader A, Pereg D, Lishner M. Are platelet volume indices of clinical use? a multidisciplinary review. Ann. Med., 2012; 44(8): 805-16. DOI: 10.3109/07853890.2011.653391

[28] Samama CM, Simon L. Detecting coagulation disorders of pregnancy: bleeding time or platelet count?. Can. J. Anaesth., 2001; 48(6): 515-8. DOI: $10.1007 / \mathrm{bf} 03016823$

[29] Douglas JT, Shah M, Lowe GD, Belch JJ, Forbes CD, Prentice CR. Plasma fibrinopeptide $\mathrm{A}$ and $\beta$-thromboglobulin in pre-eclampsia and pregnancy hypertension. Thromb. Haemost., 1982; 47: 54-5.

[30] Romero R, Snyder E, Scott D, Oyarzun E, Hobbins JC, Duffy TP. Beta-thromboglobulin during normal pregnancy, labor, and puerperium. Am. J. Perinatol., 1988; 5(2): 109-12. DOI: 10.1055/s2007-999667

[31] Ayhan A, Akkok E, Urman B, Yarali H, Dundar S, Kirazli S. $\beta$ thromboglobulin and platelet factor 4 levels in pregnancy and preeclampsia. Gynecol. Obstet. Invest., 1990; 30(1): 12-4. DOI: $10.1159 / 000293203$

[32] Leal CA, Leal DB, Adefegha SA, Morsch VM, da Silva JE, Rezer $\mathrm{JF}$, et al. Platelet aggregation and serum adenosine deaminase (ADA) activity in pregnancy associated with diabetes, hypertension and HIV. Cell Biochem. Funct., 2016; 34: 343-50. DOI: $10.1002 / \mathrm{cbf} .3197$

[33] Lok CA, Van Der Post JA, Sargent IL, Hau CM, Sturk A, Boer K, et al. Changes in microparticle numbers and cellular origin during pregnancy and preeclampsia. Hypertens. Pregnancy, 2008; 27(4): 344-60. DOI: 10.1080/10641950801955733

[34] Wong AE, Kwaan HC, Grobman WA, Weiss I, Wong CA. Microparticle source and tissue factor expression in pregnancy. Ann. Hematol., 2015; 94(8): 1285-90. DOI: 10.1007/s00277-0152355-6

[35] Davies JR, Fernando R, Hallworth SP. Hemostatic function in healthy pregnant and preeclamptic women: an assessment using the platelet function analyzer (PFA-100) and thromboelastograph. Anesth. Analg., 2007; 104(2): 416-20.

DOI: 10.1213/01.ane.0000253510.00213.05

[36] Vincelot A, Nathan N, Collet D, Mehaddi Y, Grandchamp P, Julia A. Platelet function during pregnancy: an evaluation using the PFA100 analyser. Br. J. Anaesth., 2001; 87(6): 890-3. DOI: $10.1093 / \mathrm{bja} / 87.6 .890$

[37] Bock M, De Haan J, Beck KH, Gutensohn K, Hertfelder HJ, Karger $\mathrm{R}$, et al. Standardization of the PFA-100(R) platelet function test in $105 \mathrm{mmol} / \mathrm{l}$ buffered citrate: effect of gender, smoking, and oral contraceptives. Br. J. Haematol., 1999; 106(4): 898-904.

[38] Louden KA, Pipkin FB, Heptinstall S, Fox SC, Mitchell JRA, Symonds EM. A longitudinal study of platelet behaviour and thromboxane production in whole blood in normal pregnancy and the puerperium. Br. J. Obstet. Gynaecol., 1990; 97: 1108-14. DOI: 10.1111/j.1471-0528.1990.tb02498.x

[39] Sheu JR, Hsiao G, Lin WY, Chen TF, Chien YY, Lin CH, et al. Mechanisms involved in agonist-induced hyperaggregability of platelets from normal pregnancy. J. Biomed. Sci., 2002; 9: 17-25. DOI: $10.1007 / \mathrm{BF} 02256574$

[40] Valera MC, Parant O, Cenac C, Arnaud C, Gallini A, Hamdi S, et al. Platelet adhesion and thrombus formation in whole blood at arterial shear rate at the end of pregnancy. Am. J. Reprod. Immunol., 2015; 74: 533-41.

[41] Burke N, Flood K, Muellers S, Murray A, Dunne E, Cotter B, et al. Reduced spontaneous platelet aggregation: a novel risk factor for 
adverse pregnancy outcome. Eur. J. Obstet. Gynecol. Reprod. Biol., 2016; 199: 132-6.

[42] Star J, Rosene K, Ferland J, DiLeone G, Hogan J, Kestin A. Flow cytometric analysis of platelet activation throughout normal gestation. Obstet. Gynecol., 1997; 90: 562-8. DOI: https://doi.org/10.1016/S0029-7844(97)00299-8

[43] Gjonnaess H, Fagerhol MK, Stormorken H. Studies on coagulation and fibrinolysis in blood from puerperal women with and without oestrogen treatment. Br. J. Obstet. Gynaecol., 1975; 82(2): 151-7. DOI: $10.1111 / \mathrm{j} .1471-0528.1975 . t b 02214 . \mathrm{x}$

[44] Stirling Y, Woolf L, North WR, Seghatchian MJ, Meade TW. Haemostasis in normal pregnancy. Thromb. Haemost., 1984; 52(2): 176-82.

[45] Prochazkova J, Slavik L, Ulehlova J, Prochazka M. The role of tissue factor in normal pregnancy and in the development of preeclampsia: a review. Biomed. Pap. Med. Fac. Univ. Palacky Olomouc Czech Repub., 2015; 159: 192-6.

DOI: $10.5507 /$ bp.2014.061

[46] Szecsi PB, Jorgensen M, Klajnbard A, Andersen MR, Colov NP, Stender S. Haemostatic reference intervals in pregnancy. Thromb. Haemost., 2010; 103(4): 718-27. DOI: 10.1160/th09-10-0704

[47] Cerneca F, Ricci G, Simeone R, Malisano M, Alberico S, Guaschino $\mathrm{S}$. Coagulation and fibrinolysis changes in normal pregnancy increased levels of procoagulants and reduced levels of inhibitors during pregnancy induce a hypercoagulable state, combined with a reactive fibrinolysis. Eur. J. Obstet. Gynecol. Reprod. Biol., 1997; 73(1): 31-6. DOI: $10.1016 / \mathrm{s} 0301-2115(97) 02734-6$

[48] Clark P, Brennand J, Conkie JA, McCall F, Greer IA, Walker ID. Activated protein $\mathrm{C}$ sensitivity, protein $\mathrm{C}$, protein $\mathrm{S}$ and coagulation in normal pregnancy. Thromb. Haemost., 1998; 79(6): 1166-70.

[49] Said JM, Ignjatovic V, Monagle PT, Walker SP, Higgins JR, Brennecke SP. Altered reference ranges for protein $\mathrm{C}$ and protein $\mathrm{S}$ during early pregnancy: implications for the diagnosis of protein $\mathrm{C}$ and protein $\mathrm{S}$ deficiency during pregnancy. Thromb. Haemost., 2010; 103(5): 984-8. DOI: 10.1160/TH09-07-0476

[50] Ataullakhanov FI, Koltsova EM, Balandina AN, Serebriyskiy II, Vuimo TA, Panteleev MA. Classic and global hemostasis testing in pregnancy and during pregnancy complications. Semin. Thromb. Hemost., 2016; 42(7): 696-716. DOI: 10.1055/s-0036-1592303

[51] Saha P, Stott D, Atalla R. Haemostatic changes in the puerperium '6 weeks postpartum' (HIP Study) - implication for maternal thromboembolism. BJOG. 2009; 116(12): 1602-12. DOI: $10.1111 / \mathrm{j} .1471-0528.2009 .02295 . \mathrm{x}$

[52] Howie PW. Blood clotting and fibrinolysis in pregnancy. Postgrad. Med. J., 1979; 55(643): 362-6. DOI: 10.1136/pgmj.55.643.362

[53] Olson JD. D-dimer: an overview of hemostasis and fibrinolysis, assays, and clinical applications. Adv. Clin. Chem., 2015; 69: 1-46. DOI: 10.1016/bs.acc.2014.12.001

[54] Rosenkranz A, Hiden M, Leschnik B, Weiss EC, Schlembach D, Lang U, et al. Calibrated automated thrombin generation in normal uncomplicated pregnancy. Thromb. Haemost., 2008; 99: 331-7. DOI: $10.1160 /$ th07-05-0359

[55] Dahlman T, Hellgren M, Blomback M. Changes in blood coagulation and fibrinolysis in the normal puerperium. Gynecol. Obstet. Invest., 1985; 20(1): 37-44. DOI: 10.1159/000298969

[56] Othman M, Falcon BJ, Kadir R. Global hemostasis in pregnancy: are we using thromboelastography to its full potential?. Semin. Thromb. Hemost., 2010; 36(7): 738-46.

DOI: $10.1055 / \mathrm{s}-0030-1265290$

[57] Antony KM, Mansouri R, Arndt M, Rocky Hui SK, Jariwala P, McMullen VM, et al. Establishing thromboelastography with platelet-function analyzer reference ranges and other measures in healthy term pregnant women. Am. J. Perinatol., 2015; 32(6): 54554. DOI: $10.1055 / \mathrm{s}-0034-1396700$

[58] Karlsson O, Sporrong T, Hillarp A, Jeppsson A, Hellgren M. Prospective longitudinal study of thromboelastography and standard hemostatic laboratory tests in healthy women during normal pregnancy. Anesth. Analg., 2012; 115(4): 890-8. DOI: 10.1213/ANE.0b013e3182652a33

[59] Huissoud C, Carrabin N, Benchaib M, Fontaine O, Levrat A, Massignon $\mathrm{D}$, et al. Coagulation assessment by rotation thrombelastometry in normal pregnancy. Thromb. Haemost., 2009; 101(4): 755-61. DOI: 10.1160/th08-06-0386 